\title{
Improving the Radiopacity of Calcium Aluminate Cement Based Blends
}

\author{
Ivone Regina de Oliveira ${ }^{a *}$, Gabriela do Vale Vieira ${ }^{a}$, Kennedy Wallace dos Santos ${ }^{a}$, Leandro José \\ Raniero ${ }^{a}$, Larissa Moreira Castro-Raucci ${ }^{b}$, Paulo Tambasco de Oliveira ${ }^{b}$, Celso Israel Fornaric, \\ Victor Carlos Pandolfelli ${ }^{d}$
}

anstituto de Pesquisa e Desenvolvimento, Universidade do Vale do Paraiba, Av. Shishima Hifumi, 2911, São José dos Campos, SP, Brazil

${ }^{b}$ Faculdade de Odontologia de Ribeirão Preto, Universidade de São Paulo, Av. do Café, s/n, Ribeirão Preto, SP, Brazil

${ }^{c}$ Laboratório Associado de Sensores e Materiais, Instituto Nacional de Pesquisas Espaciais, 12245-970, São José dos Campos, SP, Brazil

${ }^{d}$ Departamento de Engenharia de Materiais, Universidade Federal de São Carlos - UFSCar, Rod. Washington Luiz, km 235, São Carlos, SP, Brazil

Received: June 25, 2017; Revised: December 02, 2017; Accepted: December 14, 2017

\begin{abstract}
The radiopacity of $\mathrm{CAC}$-based compositions containing additives ( $\mathrm{ZnO}, \mathrm{Ag}$ and $\mathrm{Bi}_{2} \mathrm{O}_{3}$ ) was evaluated by optical density measurements, cold crushing strength, apparent porosity, pore size distribution, in vitro apatite-formation ability (bioactivity) and cell viability. The bioactivity was assessed via $\mathrm{pH}$ and calcium concentration measurements in simulated body fluid (SBF) for samples previously treated or not with sodium silicate (SS) solution. The surface of the samples after treatment was analyzed by scanning electron microscopy, energy dispersive X-ray analysis and confocal Raman spectroscopy. Cell viability was evaluated by MTT and alkaline phosphatase (ALP) activity. Radiopacity results confirmed that compositions containing $\mathrm{ZnO}-\mathrm{Ag}(25: 1 \mathrm{wt} \%)$ and $\mathrm{ZnO}-\mathrm{Bi}_{2} \mathrm{O}_{3}(15: 10 \mathrm{wt} \%)$ presented suitable values of radiopacity $(>3 \mathrm{mmAl})$. The identification of calcium and mainly phosphorus by EDX, highlighted the generation of an apatite-like layer on the compositions' surface after immersion in $\mathrm{SBF}$ or $\mathrm{SBF} / \mathrm{SS}$. CAC-blend containing $25 \mathrm{wt} \% \mathrm{ZnO}, \mathrm{ZnO}-\mathrm{Ag}$ and $\mathrm{ZnO}-\mathrm{Bi}_{2} \mathrm{O}_{3}$ presented slightly lower cell viability compared to the positive control.
\end{abstract}

Keywords: calcium aluminate blends, bioactivity, osteoblastic cell viability, radiopacity.

\section{Introduction}

Calcium aluminate cement (CAC) has great potential as biomaterial for repairing bone defects, as its chemical composition and thermal expansion coefficient are similar to teeth and human bones ${ }^{1,2}$. Mixtures of CAC + zirconia containing compositions were developed to stabilize compressive vertebrae fractures, leading to similar mechanical strength values to PMMA (polymethyl methacrylate) ${ }^{3}$. When evaluated in sheep's vertebrae, CAC-based mixtures showed less inflammation and better compatibility to the bone tissue than $\mathrm{PMMA}^{3}$.

Recently, some of the authors ${ }^{4}$ evaluated the properties of CAC-based mixtures containing different amounts of various compounds (alumina, zirconia, zinc oxide, hydroxyapatite, tricalcium phosphate, chitosan or collagen) and compared them with commercial products used in dentistry (MTA and glass ionomers) and orthopedics (PMMA). Particularly, 4 $\mathrm{wt} \%$ zinc oxide-containing mixture attained similar or higher mechanical strength than PMMA.

Considering that biomaterials for fractured vertebrae treatments must present high mechanical resistance due

*e-mail: ivoneregina.oliveira@gmail.com to the stresses faced ${ }^{3}$, compositions with zinc oxide were the most promising ones ${ }^{4}$. Besides that, $\mathrm{ZnO}$-containing composites are non-cytotoxic and have the ability to induce the precipitation of important compounds for the mineralization process when in the presence of the simulated body fluid (SBF) solution. Not only $\mathrm{Zn}_{3}\left(\mathrm{PO}_{4}\right)_{2}$, but also hydroxyapatite and other phosphates are expected to be generated when $\mathrm{ZnO}$ is applied as biomaterial ${ }^{5}$.

However, a CAC-based blend containing $4 \mathrm{wt} \%$ of zinc oxide did not present suitable radiopacity ${ }^{4}$, which is an indispensable requirement for dental materials, as it enables professional dentists to identify and delimitate the tooth-restoration interface. Low radiopacity biomaterials may lead to erroneous analysis ${ }^{6}$. Furthermore, high radiopacity is required for some vertebral compression fracture treatments that require cement injections. In this case, properly identifying the biomaterial after application is fundamental to prevent the material leaking to the spine or veins ${ }^{3}$. ISO $6876 / 2001$ standards established that endodontic filling materials should present radiopacity higher than $3.0 \mathrm{~mm} \mathrm{Al}$. According to ANSI/ADA, endodontic cements should be at least $2.0 \mathrm{~mm}$ Al more radiopaque than dentin or bone ${ }^{7}$. 
Material radiopacity is changed by adding a suitable content of particles containing heavy metals such as bismuth $(Z=83)$, silver $(Z=47)$ or zinc $(Z=30)^{8,9}$. Zinc oxide is used in dental materials for prosthetic and implant purposes and does not present toxicity ${ }^{10}$. Some formulations comprise zinc oxide to which silver is added to increase the radiopacity ${ }^{11}$. The drawback is that silver is prone to induce discoloration of the dentine. This is a particular problem for the coronal access cavity and affects the tooth appearance. Sealer formulations have replaced silver by bismuth compounds ${ }^{11}$, which is a well-known radiopacifying agent. MTA contains a high content of bismuth oxide and shows high radiopacity levels as a consequence of the X-ray absorption of this compound ${ }^{6}$. Nevertheless, some investigations reported that this additive can induce porosity and reduce the mechanical strength of cement-based samples ${ }^{12,13}$. A mixture of $15 \% \mathrm{ZnO}: 10 \% \mathrm{Bi}_{2} \mathrm{O}_{3}$ added to calcium aluminate cement resulted in suitable radiopacity values $(>3.0 \mathrm{~mm} \mathrm{Al})$ for clinical purposes, without affecting the mechanical properties of the samples ${ }^{13}$.

Considering these aspects, this paper focuses on evaluating the bioactivity and cell viability of CAC blends by adding $\mathrm{ZnO}-\mathrm{Ag}(25: 1 \mathrm{wt} \%)$ and $\mathrm{ZnO}-\mathrm{Bi}_{2} \mathrm{O}_{3}(15: 10 \mathrm{wt} \%)$ when compared to $\mathrm{ZnO}$ containing composition (4 and $25 \mathrm{wt} \%$ ).

The bioactivity of ceramics is defined by its reaction with the body fluid. Bioactive ceramics form a layer of biologically active bone-like apatite on their surfaces after being implanted in bone defects. It is therefore, an important indicative when ceramic materials build-up a bone-like apatite layer on their surfaces after exposure to the body environment ${ }^{14}$. One common method that has been used for testing in vitro bioactivity is to quantify the apatite-formation ability in $\mathrm{SBF}^{15,16}$. The detection of apatite formation on the surface of a material in SBF is useful for predicting the in vivo bone bioactivity of the material. Furthermore, it can help to reduce both the number of animals used for testing and the time length of the experiments, speeding up the development of new types of bioactive materials ${ }^{15}$. In vitro cytotoxicity studies (or cell viability) are also powerful and simple tools to assess biocompatibilty of new materials. These tests complement the in vitro apatite deposition results, which are also presented in this work.

\section{Experimental Procedures}

Compositions in this study were prepared by dry-ballmixing for $1 \mathrm{~h}$ calcium aluminate cement (Kerneos Aluminates, France $\left.{ }^{17}\right)$ with a dispersant Castament FS60 (0.6 wt \%, Basf, Germany) and a plasticizer $\mathrm{CaCl}_{2} .2 \mathrm{H}_{2} \mathrm{O}(2.8 \mathrm{wt} \%$, Labsynth, Brazil). For this general composition, called $\mathrm{CACH}$, either one of the following high purity radiopacifiers additives was used: (1) zinc oxide ( $\mathrm{ZnO}, \mathrm{D}_{50}=0.8 \mu \mathrm{m}$, Synth, Brazil), (2) silver (Ag, $\mathrm{D}_{50}=6.0 \mu \mathrm{m}, \mathrm{MH}$ Nano, Brazil), (3) bismuth oxide $\left(\mathrm{Bi}_{2} \mathrm{O}_{3}, \mathrm{D}_{50}=8.0 \mu \mathrm{m}\right.$, Vetec, Brazil) or their mixtures.
After the additive incorporation, materials were dry-ballmixed for $1 \mathrm{~h}$ resulting in the following compositions: (1) $\mathrm{CACH}$, (2) CACH-ZnO (4 and 25 wt\%), (3) CACH-Ag (1 wt \%), (4) CACH-Bi $\mathrm{O}_{3}(25 \mathrm{wt} \%)$, (5) CACH-ZnO-Ag (25:1 $\mathrm{wt} \%$ ), and (6) $\mathrm{CACH}-\mathrm{ZnO}-\mathrm{Bi}_{2} \mathrm{O}_{3}(15: 10 \mathrm{wt} \%)$. Following that, aqueous suspensions ( $80 \mathrm{wt} \%$ of solids) were prepared using a lab mixer and cylindrical samples were molded (diameter $=10 \mathrm{~mm}$ and height $=1 \mathrm{~mm}$ ) for measurements of radiopacity. Some of these compositions were selected for other tests. Cylindrical samples were also molded (diameter $=10 \mathrm{~mm}$ and height $=1 \mathrm{~mm}$ ) for measurements of the apatite-forming ability on their surfaces. Other sets of these samples (diameter $=16 \mathrm{~mm}$ and height $=18 \mathrm{~mm}$ ) were prepared to analyze their properties (cold crushing strength, apparent porosity and pore size distribution) and for $\mathrm{pH}$ and calcium concentration measurements (diameter $=11 \mathrm{~mm}$ and height $=4 \mathrm{~mm}$ ). The samples were kept at $37^{\circ} \mathrm{C}$ for $24 \mathrm{~h}$ in a water saturated environment, demolded and dried at $37^{\circ} \mathrm{C}$ for another $24 \mathrm{~h}$.

Radiopacity measurements consisted of placing the samples on aluminum stair steps (99\%, alloy 1100 ) with a thickness of 1-10 mm above an occlusal film (Insight Carestream dental, Kodak) IO-41 Oclusal (REF 1169143, Lot 56301405). Tests were carried out in $\mathrm{X}$ ray equipment (Procion, ION 70X, Brazil, $70 \mathrm{KV}$ and $8 \mathrm{~mA}$ ). The focus-object distance was $20 \mathrm{~cm}$ and the exposition time was $0.32 \mathrm{~s}$. The films were manually processed in a dark room according to the time/ temperature ratio recommended by the manufacturer (Kodak, Manaus, Brazil), where they were initially kept for $3 \mathrm{~min}$ in an $\mathrm{X}$ ray developing solution, washed in water for $30 \mathrm{~s}$, placed in a fixing solution for $3 \mathrm{~min}$, washed again in water for $10 \mathrm{~min}$ and dried. Based on the attained radiographs, the optical density (OD) of the samples and for each step of the aluminum stack was defined using a photo densitometer (MRA Industry Electronic Equipment Ltd., Ribeirão Preto, Brazil). The optical density results obtained from this study represent an average of 4 measurements carried out for each composition. The collected data were also adjusted by a polynomial fitting in order to obtain the equivalent value of radiopacity in $\mathrm{mm} \mathrm{Al}$.

Uniaxial cold crushing strength tests (ISO 9917-1) of five samples of each prepared composition were carried out under a crosshead rate of $0.15 \mathrm{~mm} / \mathrm{min}$ in mechanical testing equipment (DL 10000, EMIC, Brazil). The modulus of rupture $\left(\sigma_{R}, \mathrm{MPa}\right)$ was calculated as follows:

$$
\sigma_{R}=\frac{4 P}{\pi D^{2}}
$$

where $P(\mathrm{~N})$ is the maximum applied load and $\mathrm{D}(\mathrm{mm})$ is the average sample diameter.

Apparent porosity (AP) was measured via the Archimedes method (ASTM C830), where the dried $\left(M_{s}\right)$, immersed $\left(M_{i}\right.$, attained after keeping the samples for $1 \mathrm{~h}$ under vacuum in 
kerosene, $\left.\rho=0.8 \mathrm{~g} / \mathrm{cm}^{3}\right)$ and humid $\left(M_{\nu}\right)$ masses of three samples for each composition were considered in order to calculate this property (Eq. 2).

$$
A P=\left(\frac{M_{u}-M_{s}}{M_{u}-M_{i}}\right) x 100
$$

Apparent porosity measurements were carried out in dried materials at $110^{\circ} \mathrm{C}$ for $24 \mathrm{~h}$, which were classified as "without treatment (WT)" tests. Other cast cylinders were also placed in contact with simulated body fluid (SBF) solution at $37^{\circ} \mathrm{C}$ for 7 days. Humid samples were then subjected to uniaxial compression tests, whereas others were dried at $110^{\circ} \mathrm{C}$ for $24 \mathrm{~h}$ and their apparent porosity was evaluated ("with SBF treatment").

For pore size distribution analysis, the samples were placed in contact with $\mathrm{SBF}^{18}$ solution at $37^{\circ} \mathrm{C}$ for 7 days followed by drying at $110^{\circ} \mathrm{C}$ for another $24 \mathrm{~h}$. Samples were evaluated using the mercury intrusion porosimetry technique (Autopore IV 9500 equipment, Micromeritics, USA) before and after treatment with SBF. This method is based on the Washburn equation (Eq. 1), where $D$ is the pore diameter, $P$ is the applied pressure $(\mathrm{Pa}), \gamma$ is the mercury surface tension $\left(\mathrm{J} / \mathrm{m}^{2}\right)$ and $\varphi$ is the contact angle assumed to be $\left(130^{\circ}\right)$ between the mercury and the sample. The mercury volume $(V)$ that penetrates the pores is directly measured as a function of the applied pressure.

$$
D=4 \gamma P^{-1} \cos (\phi)
$$

For $\mathrm{pH}$ and calcium concentration evaluations, samples were placed into plastic containers with $33 \mathrm{~mL}$ of SBF solutions and kept at $37^{\circ} \mathrm{C}$ for 21 days. The measurements were carried out at certain time intervals, using a $\mathrm{pH}$ sensor connected to an automatic data recorder system (MA 522/E, Marconi, Piracicaba, Brazil) and a selective sensor for calcium ions (series 930, Aprolab, Brazil).

According to the literature ${ }^{19}$,samples were also placed into plastic containers with $19 \mathrm{~mL}$ of SBF solutions in order to maintain a surface area to $\mathrm{SBF}$ volume ratio of $0.1 \mathrm{~cm}^{-1}$, because this ratio affects the in vitro degradation process of bioactive materials. Afterwards, the samples were kept for 21 days under stirring at $37^{\circ} \mathrm{C}$ with the help of a shaker (MA420, Marconi) and gently rinsed with deionized water, followed by drying at room temperature ${ }^{19}$.

The surfaces of the gold-coated samples were analyzed by scanning electron microscopy (SEM, EVO MA10 Zeiss) and energy dispersive X-ray analysis (EDX). The surfaces of the samples were also analyzed by confocal Raman spectroscopy (Rivers diagnostic system, model 3510) coupled to a red laser with a $785 \mathrm{~nm}$ wavelength and X-ray diffraction (Philips X'Pert MRD high-resolution diffractometer) using the thin film configuration. In this configuration, the $\mathrm{Cu} \mathrm{X}$-ray tube is set to line focus. The incident beam optics is composed of a Ni filter, a Soller slit and a $1 / 8^{\circ}$ divergence slit. The diffracted beam optics uses a parallel beam collimator and a flat crystal graphite monochromator before the detector. Using this configuration, it is possible to perform grazing incidence X-ray diffraction measurements at varied incidence angles $(\omega)$. The data analysis was performed using X'Pert Quantify computational package.

The same tests described above were also carried out using samples previously treated for 7 days with sodium silicate (SS) solution (33 or $19 \mathrm{~mL}$ depending on the sample size).

The SBF solution was prepared as described in Table 1, using the reactants amount/inorganic ions concentration ratio higher than 1.5 (SBF 1.5) in order to speed up the apatite generation.

Table 1. Reagents used to prepare $1 \mathrm{~L}$ of simulated body fluid solution (SBF).

\begin{tabular}{cc}
\hline Reagents & SBF 1.5 \\
\hline water & $400 \mathrm{~mL}$ \\
$\mathrm{NaCl}$ & $11.992 \mathrm{~g}$ \\
$\mathrm{NaHCO}_{3}$ & $0.529 \mathrm{~g}$ \\
$\mathrm{KCl}$ & $0.335 \mathrm{~g}$ \\
$\mathrm{~K}_{2} \mathrm{HPO}_{4}$ & $0.261 \mathrm{~g}$ \\
$\mathrm{MgCl}_{2} \cdot 6 \mathrm{H}_{2} \mathrm{O}$ & $0.458 \mathrm{~g}$ \\
$\mathrm{HCl}_{0.1 \mathrm{M}}$ & $15 \mathrm{ml}$ \\
$\mathrm{CaCl}_{2} .2 \mathrm{H}_{2} \mathrm{O}$ & $0.551 \mathrm{~g}$ \\
$\mathrm{Na}_{2} \mathrm{SO}_{4}$ & $0.107 \mathrm{~g}$ \\
$\left(\mathrm{CH}_{2} \mathrm{OH}\right)_{3} \mathrm{CNH}_{2} 0.05 \mathrm{M}$ & Required amount to adjust $\mathrm{pH}=7.25$ \\
$\mathrm{HCl}_{0.1 \mathrm{M}}$ & Required amount to adjust $\mathrm{pH}=7.25$ \\
\hline
\end{tabular}

For the cell viability analysis, samples (diameter $=6$ $\mathrm{mm}$ and height $=2 \mathrm{~mm}$ ) were prepared and demolded under sterile conditions (laminar flow cabinet) and cured at $37^{\circ} \mathrm{C}$ for 24 hours in a saturated environment (relative humidity $=$ $100 \%$ ). After that, samples were dry-sterilized at $110^{\circ} \mathrm{C}$ for 24 hours, followed by exposure to an ultraviolet germicidal lamp for 20 minutes.

Osteoblastic cells derived from human osteosarcoma (SAOS-2, ATCC HTB-85) were grown as monolayer cultures in T-75 flasks (Corning Inc., NY, EUA) containing $10 \mathrm{~mL}$ of McCoy's 5A medium (Sigma St Louis, MO, EUA), which was enriched with $15 \%$ fetal bovine serum (Invitrogen, Carlsbad, CA, EUA), $100 \mathrm{ug} / \mathrm{mL}$ of streptomycin and $100 \mathrm{UI} / \mathrm{mL}$ of penicillin (Gibco, Gran Island, NY, EUA). This enriched medium was kept at $37^{\circ} \mathrm{C}$ in a humidified environment containing $5 \% \mathrm{CO}_{2}$ and $95 \%$ of atmospheric air. After confluence (a condition where a suitable number of adherent cells in a culture dish is attained), the cells were detached with ethylenediaminetetraacetic acid (EDTA solution - $1 \mathrm{mM}$, Gibco) and trypsin $(0.25 \%$, Gibco) for 2 minutes. A fixed cell quantity $\left(2 \times 10^{4}\right)$ was analysed in triplicate, using a culture dish with 24 -wells. The cells were cultivated in an osteogenic medium enriched with $7 \mathrm{mM}$ of 
$\beta$-glicerophosphate (Sigma) and $50 \mu \mathrm{g} / \mathrm{mL}$ of ascorbic acid (Sigma) for 24 hours.

The samples were placed on polycarbonate membrane inserts (pore size $3 \mu \mathrm{m}$, Greiner Transwell) and the cell exposure was carried out for periods up to 7 days. Nonexposed cultures and those exposed to culture medium containing $10 \mathrm{vol} \%$ of dimethyl sulfoxide (DMSO) were used as positive and negative controls, respectively.

One day after the samples' exposure to the cell culture, the cell viability test (which evaluates the cell ability to maintain or recover viability) was carried out via 3-[4,5-dimethylthiazol-2-yl]-2,5- diphenyl tetrazolium bromide (MTT, Sigma) reduction ${ }^{20}$. In this test, a culture medium containing $10 \mathrm{vol} \%$ of MTT $(5 \mathrm{mg} / \mathrm{mL})$ was added to the wells. The culture dish was incubated at $37^{\circ} \mathrm{C}$ for 4 hours in a humidified environment containing $5 \% \mathrm{CO}_{2}$ and $95 \%$ of atmospheric air. After this period, the cultures were washed in $1 \mathrm{ml}$ of warmed phosphate-buffered saline (PBS, Gibco, Glasgow, UK). Afterwards, $1 \mathrm{~mL}$ of acid-isopropanol solution (100 mL of 2-propanol and $134 \mu \mathrm{L}$ oh HCl) (Sigma) was added to each well. The culture dishes were stirred for 5 minutes to complete solubilization of the precipitate formed and $150 \mu \mathrm{L}$ of the solution was transferred to a new culture dish for optical density reading $(570 \mathrm{~nm} ; \mu$ Quant, Biotek, Winooski, VT, USA). The results were expressed as absorbance and the comparisons were carried out using the non-parametric Kruskal-Wallis test (One-way ANOVA) for independent samples, followed by the Student-NewmanKeuls method, when appropriate. The level of significance was established at $5 \%$.

On day 7, the in-situ ALP activity was evaluated by Fast red TR dye marking ${ }^{21}$. The culture medium was withdrawn and the wells were washed in $1 \mathrm{~mL}$ of PBS heated up to 37 ${ }^{\circ} \mathrm{C}$. After that, $1 \mathrm{~mL}$ of tris-buffered solution $(120 \mathrm{mM}, \mathrm{pH}$ 8.4, Sigma-Aldrich, St. Louis, MO, USA) containing Fast red TR (1.8 mM, Sigma), naphthol-AS-MX-phosphate (0.9 $\mathrm{mM}$, Sigma) and dimetilformamide (1:9, Merck) was added to each well, followed by incubation in culture conditions for 30 minutes. Macroscopic images of the cultures were obtained for qualitative assessment of ALP activity.

\section{Results and Discussions}

The radiopacity for each tested composition, expressed in millimeters of equivalent aluminum, is shown in Figure 1. As expected, a decrease in OD was observed with an increase in the radiopacity ${ }^{10}$. The results confirmed that the CAC-based composition containing $\mathrm{ZnO}-\mathrm{Bi}_{2} \mathrm{O}_{3}(15: 10 \mathrm{wt} \%)$ presented a suitable value of radiopacity $(>3 \mathrm{mmAl})$ which is higher compared to those containing $\mathrm{ZnO}$ ( 4 and $25 \mathrm{wt} \%$ ). On the other hand, the $\mathrm{ZnO}-\mathrm{Ag}(25: 1 \mathrm{wt} \%)$ composition presented suitable radiopacity (nearly $3 \mathrm{mmAl}$ ) for clinical purposes and both (with $\mathrm{Bi}_{2} \mathrm{O}_{3}$ or Ag) fit the ISO 6876/20017.

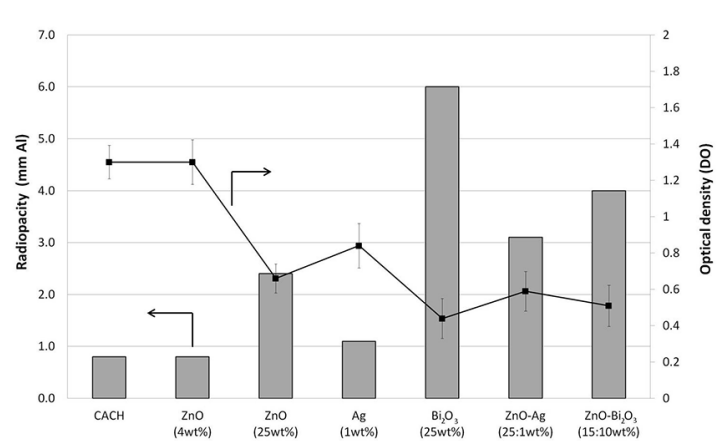

Figure 1. Mean radiopacity values expressed as aluminum thickness $(\mathrm{mm} \mathrm{Al})$ and the optical density for the compositions: $\mathrm{CACH}, \mathrm{CACH}-$ $\mathrm{ZnO}$ (4 and $25 \mathrm{wt} \%$ ), CACH-Ag ( $1 \mathrm{wt} \%$ ), $\mathrm{CACH}-\mathrm{Bi}_{2} \mathrm{O}_{3}(25 \mathrm{wt} \%)$, $\mathrm{CACH}-\mathrm{ZnO}-\mathrm{Ag}(25: 1 \mathrm{wt} \%)$, and $\mathrm{CACH}-\mathrm{ZnO}-\mathrm{Bi}_{2} \mathrm{O}_{3}(15: 10 \mathrm{wt} \%)$.

The crushing strength attained for the evaluated samples is also an important property, especially when considering likely candidates for orthopedic applications. For these applications, the material should present mechanical properties in agreement with the specific function of the implant. Thus, in this study, some compositions were also evaluated under uniaxial cold crushing strength after 7 days of curing in SBF (Table 2). The blends showed lower mechanical values than cortical bone (130-190 MPa). Apparent porosity results before and after the samples' contact with the SBF solution at $37^{\circ} \mathrm{C}$ for 7 days are also presented in Table 2. Ag radiopacifier compound resulted in the highest values even when added at a lower content. The lower benefit of $\mathrm{Bi}_{2} \mathrm{O}_{3}$, although it is the best radiopacifier additive, is associated to their particle morphology having an elongated shape resulting in higher porosity and smaller mechanical strength ${ }^{13}$. All compositions showed a reduction in the apparent porosity after treatment with the SBF solution.

The pore size distribution of the sample containing 4 $\mathrm{wt} \%$ of $\mathrm{ZnO}$ was also affected by the higher addition of this oxide ( $25 \mathrm{wt} \%$ ) or when combined with $\mathrm{Ag}$ and $\mathrm{Bi}_{2} \mathrm{O}_{3}$, as shown in Figure 2, leading to smaller pores before their contact with the SBF solution.

Figure $2 \mathrm{~b}$ also shows a significant displacement of the pore size distribution for lower values after the treatment with the SBF solution. This trend was observed for all studied compositions. This behavior can be associated to apatite precipitation on the materials' surface in SBF solution indicating its bioactivity ${ }^{5}$, as the precipitated phosphates (derived from the interaction of the cements with the compounds available in the SBF solution) coat the solid surface and fill in the pores, reducing their apparent porosity after treatment with the SBF. Consequently, the overall pore size of the studied samples was greatly reduced when compared to the materials before their treatment with SBF. SBF is metastable and it will attain thermodynamic stability by forming precipitates, including different $\mathrm{CaP}$ phases. Hydroxyapatite is the most thermodynamically stable phase in the SBF solution ${ }^{22}$. 
Table 2. Uniaxial cold crushing strength and apparent porosity for the compositions evaluated.

\begin{tabular}{cccc}
\hline Compositions & $\begin{array}{c}\text { Uniaxial cold crushing strength } \\
(\mathrm{MPa})\end{array}$ & $\begin{array}{c}\text { Apparent porosity } \\
\text { (without SBF) } \%\end{array}$ & $\begin{array}{c}\text { Apparent porosity } \\
\text { (with SBF) \% }\end{array}$ \\
\hline $\mathrm{ZnO}(4 \mathrm{wt} \%)$ & $93.3 \pm 11.2$ & $11.9 \pm 0.4$ & $2.1 \pm 0.2$ \\
$\mathrm{ZnO}(25 \mathrm{wt} \%)$ & $99.4 \pm 3.2$ & $16.3 \pm 0.7$ & $3.0 \pm 0.2$ \\
$\mathrm{ZnO}: \mathrm{Ag}(25: 1 \mathrm{wt} \%)$ & $101.5 \pm 5.0$ & $17.4 \pm 0.1$ & $2.8 \pm 0.3$ \\
$\mathrm{ZnO}: \mathrm{Bi}_{2} \mathrm{O}_{3}(15: 10 \mathrm{wt} \%)$ & $93.4 \pm 1.8$ & $18.0 \pm 0.3$ & $2.6 \pm 0.3$ \\
\hline
\end{tabular}

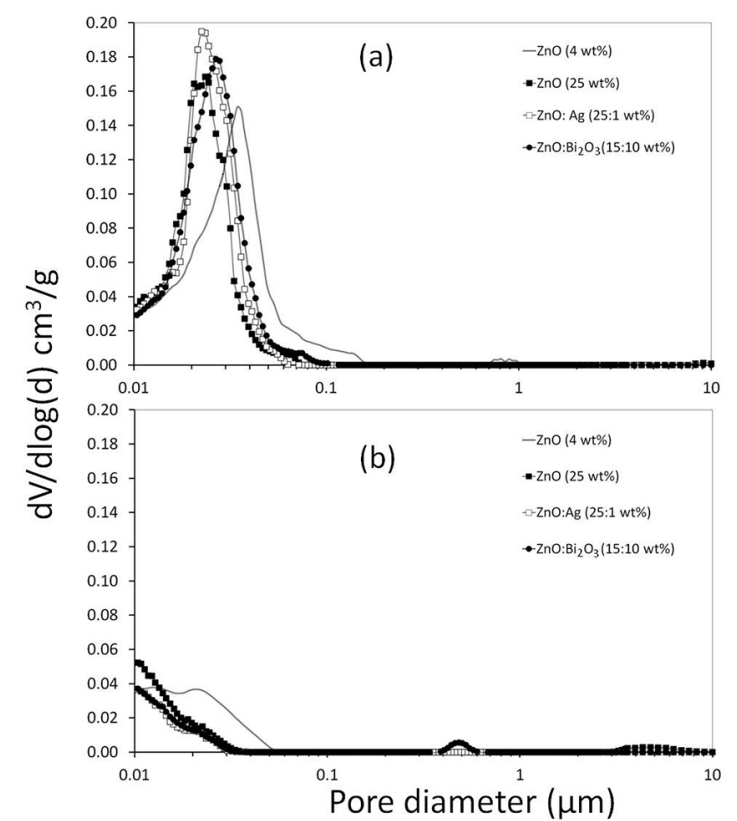

Figure 2. Pore size distribution for CACH-ZnO (4 wt $\%)$, CACH$\mathrm{ZnO}(25 \mathrm{wt} \%), \mathrm{CACH}-\mathrm{ZnO}-\mathrm{Ag}(25: 1 \mathrm{wt} \%)$ and $\mathrm{CACH}-\mathrm{ZnO}-\mathrm{Bi}_{2} \mathrm{O}_{3}$ $(15: 10 \mathrm{wt} \%)$ compositions. All samples were evaluated (a) before and (b) after their contact for 7 days with the simulated body fluid (SBF) solution at $37^{\circ} \mathrm{C}$.
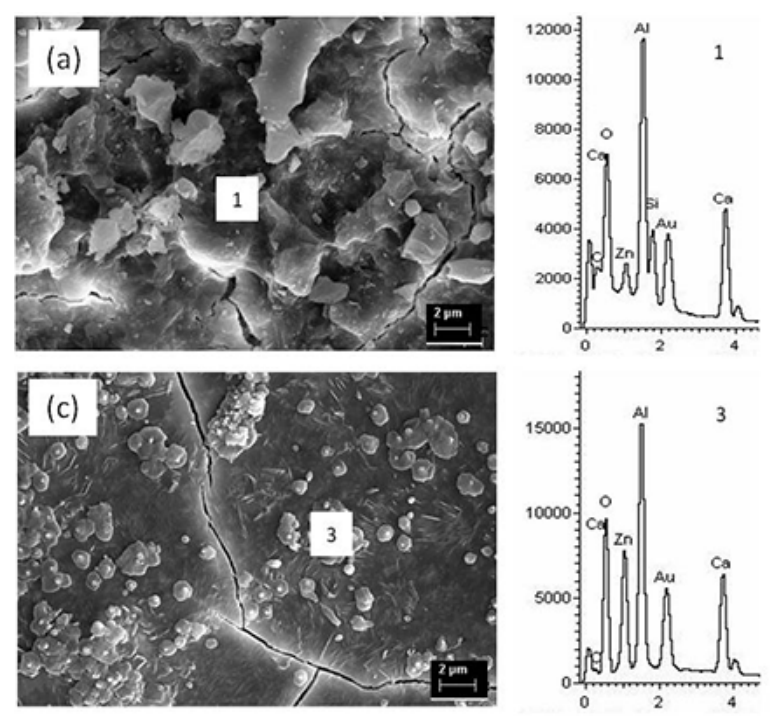

This coating is an ideal method to produce hydroxyapatite layers on materials for biomedical applications. By this method, a bone-like apatite surface can be produced in an acellular SBF, where the ions present are similar to those of the inorganic compounds of human blood plasma. Two steps are involved in the process: i) nucleation and ii) precipitation and growth of the apatite layer ${ }^{23}$.

Scanning electron microscopy (SEM) and energy dispersive X-ray analysis (EDX) of compositions' samples without treatment in SBF are shown in Figure 3. SEM and EDX after SBF without previous treatment and after their contact for 7 days with sodium silicate (SS) solution at $37^{\circ} \mathrm{C}$, are shown in Figure 4 . The surface $\mathrm{Ca} / \mathrm{P}$ ratios of the blends after immersion in SBF without previous treatment and after their contact with SS, were quantified by EDX and shown in Table 3.

SEM analyses attested that the precipitation of phases occurred on the samples' surface, before (SBF) and after their contact with sodium silicate solution (SBF/SS). The addition of silver and bismuth oxide did not affect the bioactivity of the samples.

The identification of calcium and mainly phosphorus by EDX highlighted the formation of calcium phosphate phases
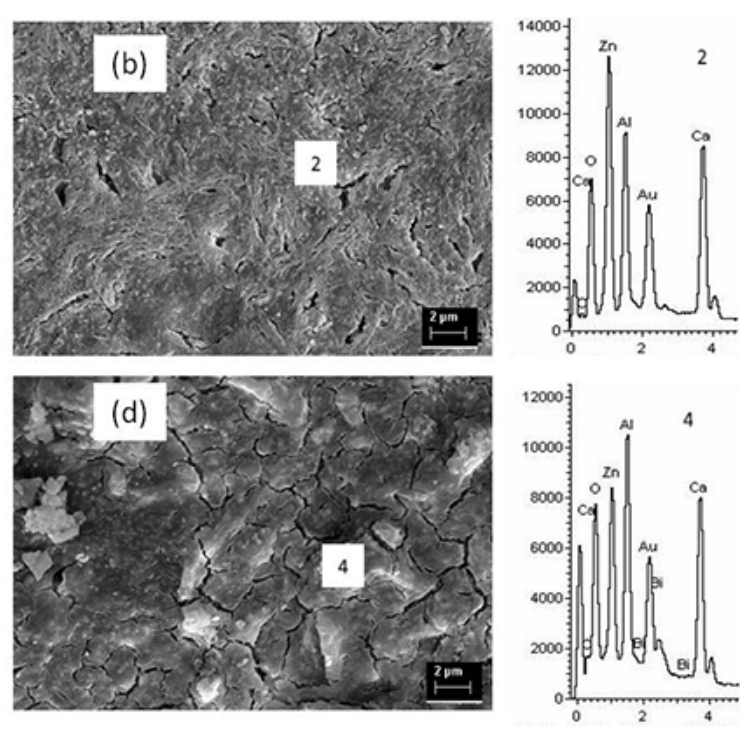

Figure 3. Scanning electron micrographs (SEM) and energy dispersive X-ray analysis (EDX) for (a) CACH-ZnO (4 wt $\%)$, (b) $\mathrm{CACH}-$ $\mathrm{ZnO}(25 \mathrm{wt} \%)$, (c) CACH-ZnO-Ag $(25: 1 \mathrm{wt} \%)$ and (d) $\mathrm{CACH}-\mathrm{ZnO}-\mathrm{Bi}_{2} \mathrm{O}_{3}(15: 10 \mathrm{wt} \%)$ without treatment in SBF. 

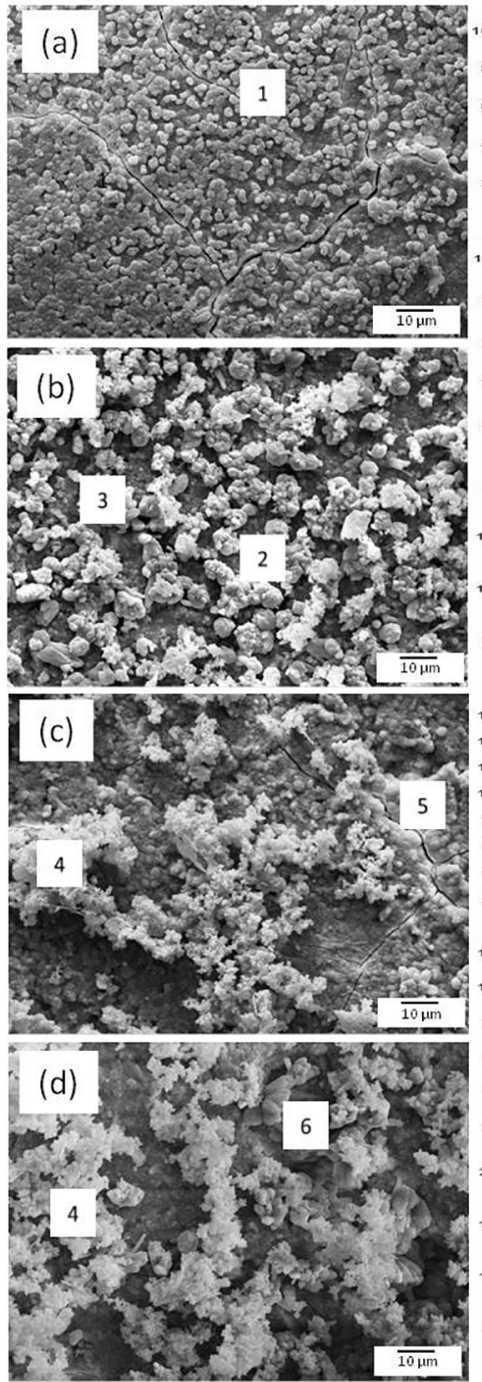
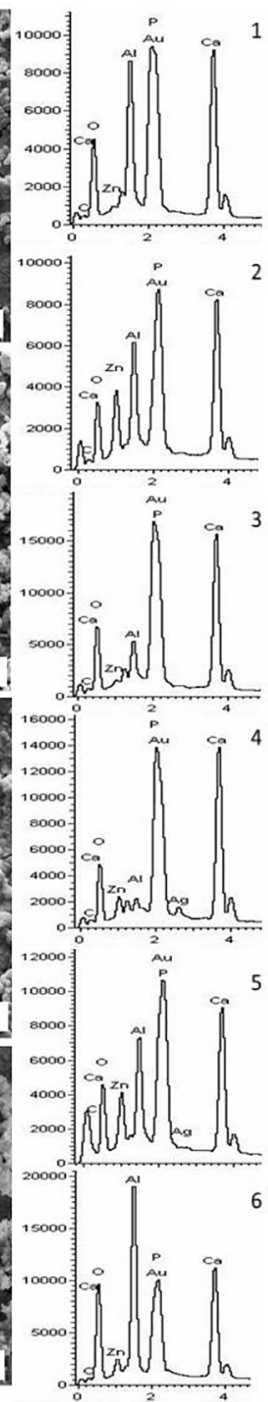
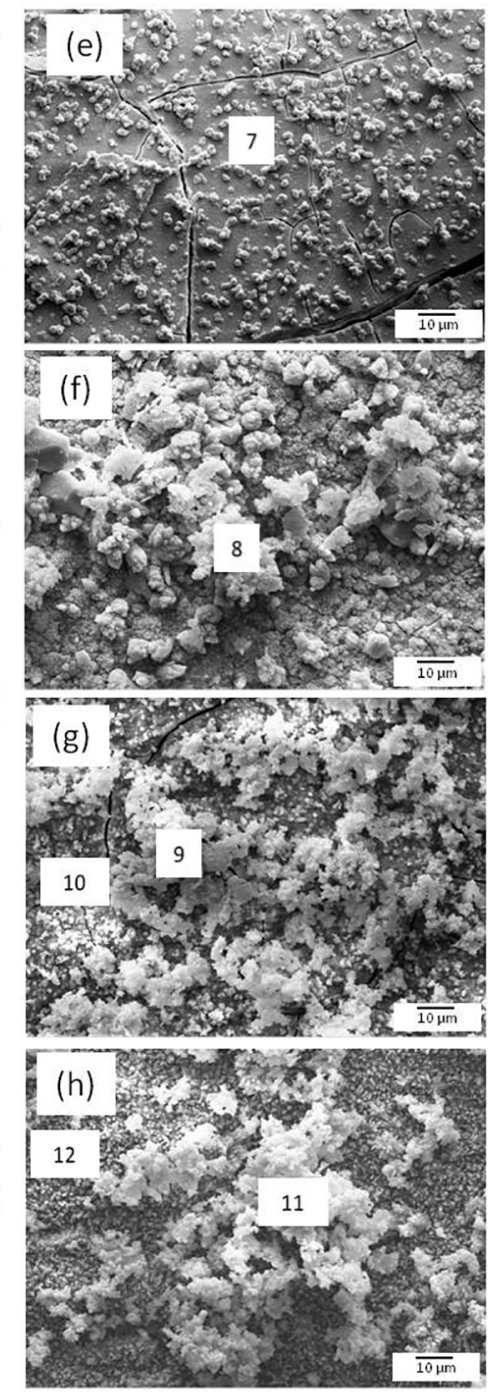
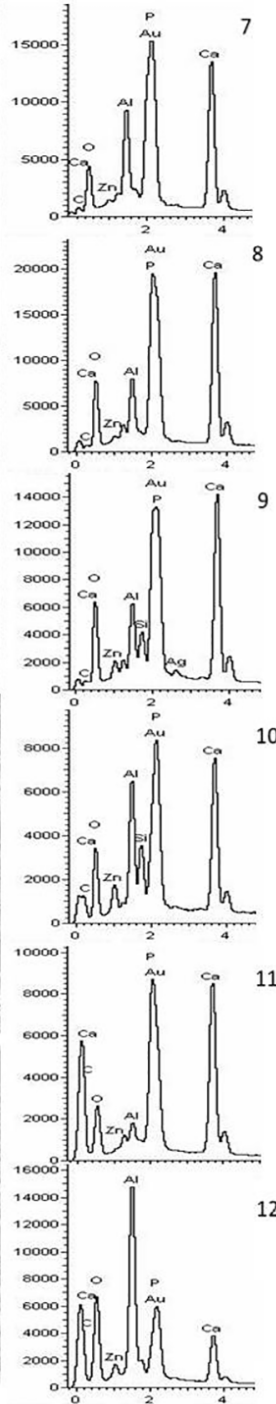

Figure 4. Scanning electron micrographs (SEM) and energy dispersive X-ray analysis (EDX) for (a, e) CACH-ZnO (4 wt $\%)$, (b, f) CACH-ZnO (25 wt\%), (c, g) CACH-ZnO-Ag (25:1 wt\%) and (d, h) CACH-ZnO-Bi $\mathrm{O}_{3}(15: 10 \mathrm{wt} \%)$. All samples were evaluated after 21 days in SBF at $37^{\circ} \mathrm{C}$ : (a-d) before treatment and (e-h) after previous treatment for 7 days with sodium silicate (SS) solution at $37^{\circ} \mathrm{C}$.

such as hydroxyapatite. In addition to these elements, the presence of aluminum was also observed. $\mathrm{CaO}$ and $\mathrm{Al}_{2} \mathrm{O}_{3}$ are the main chemical constituents of $\mathrm{CAC}$ which comprises $\mathrm{CA}$ and $\mathrm{CA}_{2}$ phases $\left(\mathrm{C}\right.$ stands for $\mathrm{CaO}$ and $\mathrm{A}$ for $\mathrm{Al}_{2} \mathrm{O}_{3}$ ). For most of the compositions $\mathrm{Ca} / \mathrm{P}$ ratio $<1.67$ was detected what strongly suggests the formation of hydroxyapatite.

Calcium phosphate coating was firstly grown on a substrate by a process using bioactive $\mathrm{CaO}-\mathrm{SiO}_{2}$-based glass that was placed in contact with the substrates to induce apatite nucleation on their surface in SBF. Silicate ions containing silanol groups are supposed to be released from the bioactive glass and adsorbed on the substrate surface to induce apatite formation ${ }^{24}$.

The silicate phase $\left(\mathrm{Ca}_{2} \mathrm{SiO}_{4}\right)$ favors the hydroxyapatite generation in SBF medium, which can also stimulate the deposition of mineralized tissue on the biomaterial surface and

Table 3. Surface $\mathrm{Ca} / \mathrm{P}$ ratio (atomic $\%$ quantified by EDX) for CACH-ZnO (4 and $25 \mathrm{wt} \%$ ), CACH-ZnO-Ag (25:1 wt $\%)$ and CACH$\mathrm{ZnO}-\mathrm{Bi} 2 \mathrm{O} 3(15: 10 \mathrm{wt} \%)$. All tests were conducted after 21 days, using samples treated with SBF or SBF/SS.

\begin{tabular}{ccc}
\hline Compositions & $\mathrm{Ca} / \mathrm{P}$ ratio in SBF & $\mathrm{Ca} / \mathrm{P}$ ratio in SBF/SS \\
\hline $\mathrm{CACH}-\mathrm{ZnO}(4 \mathrm{wt} \%)$ & $1.41 \pm 0.06$ & $1.97 \pm 0.02$ \\
$\mathrm{CACH}-\mathrm{ZnO}(25 \mathrm{wt} \%)$ & $1.55 \pm 0.34$ & $1.61 \pm 0.27$ \\
$\mathrm{CACH}-\mathrm{ZnO}-\mathrm{Ag}(25: 1 \mathrm{wt} \%)$ & $1.45 \pm 0.21$ & $1.49 \pm 0.16$ \\
$\mathrm{CACH}-\mathrm{ZnO}-\mathrm{Bi}_{2} \mathrm{O}_{3}(15: 10 \mathrm{wt} \%)$ & $1.39 \pm 0.06$ & $1.46 \pm 0.07$ \\
\hline
\end{tabular}


induce further integration of the latter with the surrounding in vivo components ${ }^{25,26}$. However, there is another method in which the nucleant agent is a sodium silicate solution (SS). After treatment of samples in SS solution, their immersion into $1.5 \mathrm{SBF}$ was carried out. This procedure is adopted so that the reactions could occur as follows: i) adsorption of silicate ions from the solution on the ceramic surface; ii) nucleation of hydroxyapatite on the adsorbed ions and iii) growth of the hydroxyapatite nuclei and the layer build up. The Si-OH groups, formed by the adsorption of the SS solution ions on the ceramic surface, induce the apatite nucleation. After that, its growth is spontaneous as a consequence of subsequent depositions of calcium and phosphates ions that are present in the solution ${ }^{23}$.

These results indicated the affinity of the hydroxyapatite precipitates with CAC-based ceramic, suggesting that the compositions studied have suitable surface features to become bioactive having excellent interaction with living tissues. Thus, it is not necessary a previous treatment with a nucleant agent such as sodium silicate solution.

An alternative technique to follow the apatite precipitation on bioactivity compounds is by measuring the $\mathrm{pH}$ evolution of the SBF solution in contact with the samples. Studies related to the interaction of osteoblastic cells with niobium pointed out the formation of a surface layer of calcium phosphate due to niobium alkalinization, which may favor the repairing process of hard tissues ${ }^{27}$. Some studies have also shown that $\alpha-\mathrm{C}_{3} \mathrm{P}$ ceramics favor proliferation and expression of osteoblasts, most likely because of the release of calcium and phosphate ions in concentrations that stimulate the osteogenic activity of cells $\mathrm{s}^{28,29}$.

Initially the contact of biomaterial with SBF induces the increase of calcium ions in the liquid medium due to the migration of such species from the solid to the solution. Afterwards, the reaction of these calcium ions with $\mathrm{PO}_{4}^{-3}$ contained in the liquid result in the precipitation of a calcium phosphate layer on the sample surface $e^{30,31}$.

Changes in the $\mathrm{Ca}^{2+}$ ions concentration in the SBF solution can also be used for this purpose, where their quantitative chemical analysis over time can help to identify the reaction stages to generate calcium phosphate layers ${ }^{30}$. The decrease of calcium ions in the SBF medium indicates the consumption of these species for the apatite formation on the samples' surface.

In fact, the increase in $\mathrm{pH}$ and calcium ions concentration reduction were detected for all compositions studied when compared to plain SBF. The $\mathrm{pH}$ and calcium concentration variation in the SBF solutions using samples before and after their contact with sodium silicate solution (SBF/SS) are shown in Figures 5 and 6, respectively. Due to the difficulty to prepare SBF solutions with high stability, spontaneous precipitation by contact with $\mathrm{CO}_{2}$ from the air during the immersion period, can occur. In order to consider this effect plain SBF was used as control. Thus, the change of $\mathrm{pH}$ and the $\mathrm{Ca}^{2+}$ concentration compared to plain SBF occurred due to the sample-SBF contact.

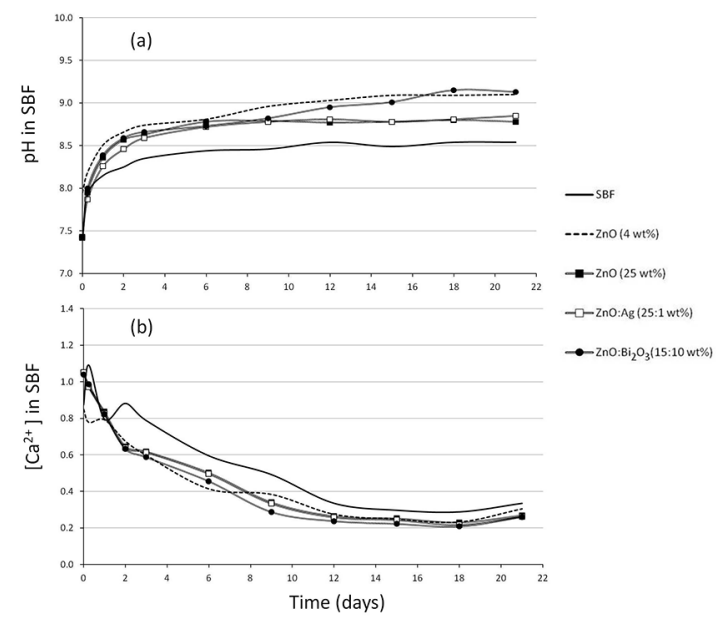

Figure 5. (a) $\mathrm{pH}$ and (b) calcium concentration variation in $\mathrm{SBF}$ as a function of the time for CACH-ZnO (4 wt $\%), \mathrm{CACH}-\mathrm{ZnO}(25$ wt $\%), \mathrm{CACH}-\mathrm{ZnO}-\mathrm{Ag}(25: 1 \mathrm{wt} \%)$ and $\mathrm{CACH}-\mathrm{ZnO}-\mathrm{Bi}_{2} \mathrm{O}_{3}(15: 10$ $\mathrm{wt} \%$ ) compositions. Pure SBF was used as control.

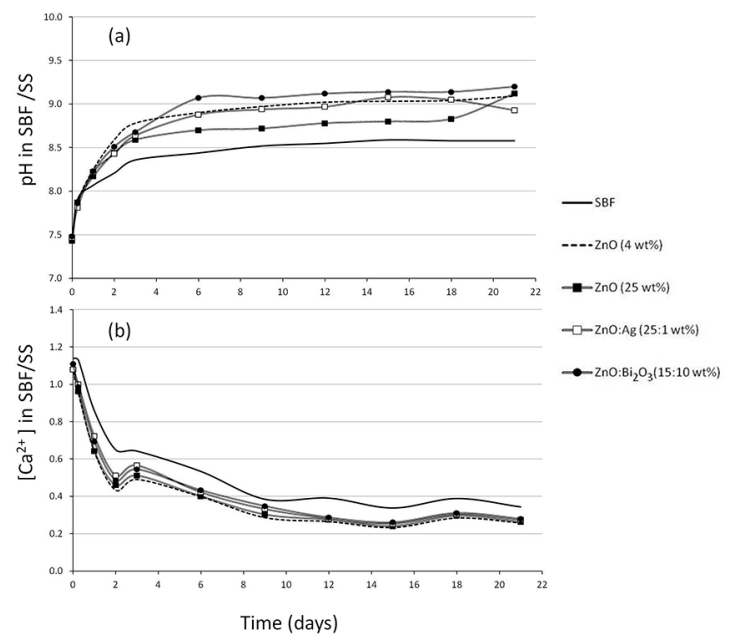

Figure 6. (a) $\mathrm{pH}$ and (b) calcium concentration variation in $\mathrm{SBF}$ as a function of the time for CACH-ZnO (4 wt $\%), \mathrm{CACH}-\mathrm{ZnO}(25$ wt $\%), \mathrm{CACH}-\mathrm{ZnO}-\mathrm{Ag}(25: 1 \mathrm{wt} \%)$ and $\mathrm{CACH}-\mathrm{ZnO}-\mathrm{Bi}_{2} \mathrm{O}_{3}(15: 10$ $\mathrm{wt} \%)$ compositions. All samples were evaluated after contact with sodium silicate (SS) solution at $37^{\circ} \mathrm{C}$ for 7 days. Pure SBF was used as control.

The in situ apatite precipitation may help to prevent the formation of secondary caries (derived from remaining voids between the filling material and the teeth) and consequently the replacement of the dental restoration. Moreover, strong bonding and apatite precipitation are parameters that make tooth restoration more similar to its original structure, which are desired features especially when comparing cements to other filling products, such as amalgam ${ }^{32}$.

The presence of the Raman signature at $960 \mathrm{~cm}^{-1}$ corresponding to the phosphate group, attests the formation of an apatite-like layer on the compositions' surfaces after immersion in SBF or SBF/SS (Figure 7).

In the range between 900 and $1100 \mathrm{~cm}^{-1}$, the presence of the functional groups $\mathrm{PO}_{4}^{3-}$ and $\mathrm{CO}_{3}{ }^{2-}$ derived from carbonate 


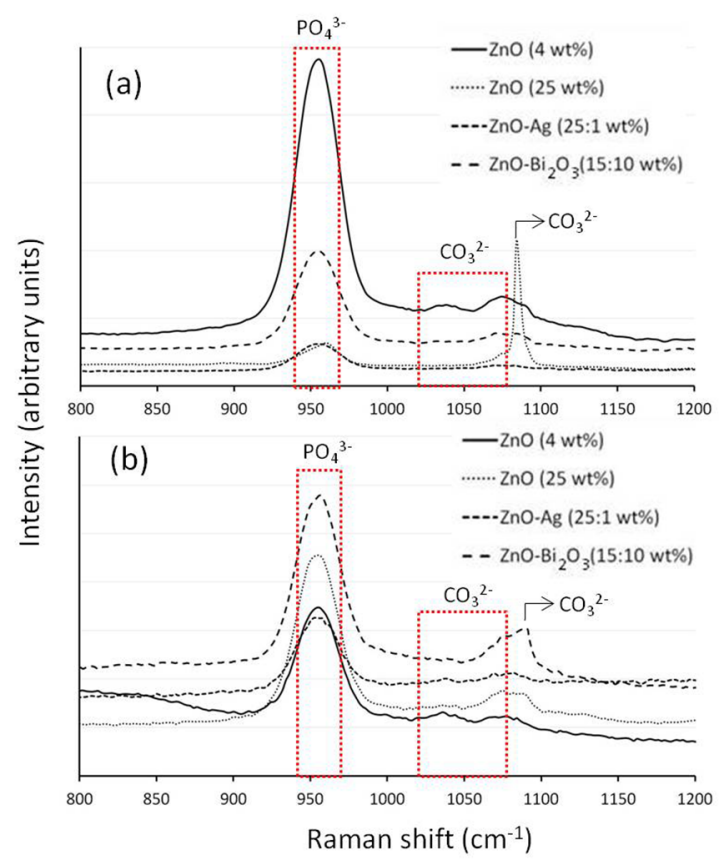

Figure 7. Raman spectra for $\mathrm{CACH}-\mathrm{ZnO}(4 \mathrm{wt} \%)$, CACH-ZnO (25 wt\%), CACH-ZnO-Ag (25:1 wt \%) and CACH-ZnO-Bi $\mathrm{O}_{3}$ $(15: 10 \mathrm{wt} \%)$. All samples were evaluated after 21 days in SBF at $37^{\circ} \mathrm{C}$, (a) without previous treatment and (b) previously treated for 7 days with sodium silicate (SS) solution at $37^{\circ} \mathrm{C}$.

hydroxyapatite is expected ${ }^{33,34}$. The latter is the main mineral phase of bone, which is a bioceramic composite that also comprises the organic phase, mainly collagen ${ }^{22}$. Type-B carbonate substitution is very frequent in bone, mainly when a phosphate ion $\left(\mathrm{PO}_{4}^{3-}\right)$ found in an apatite crystal is replaced by a carbonate ion $\left(\mathrm{CO}_{3}^{2-}\right)^{35}$.

The Raman spectrum of the main vibrational modes of carbonate hydroxyapatite (enamel) showed peaks at 586 $\mathrm{cm}^{-1}$, attributed to phosphate ${ }_{14} \mathrm{PO}_{4}{ }^{3-}$ vibrations, and at 960 $\mathrm{cm}^{-1}$, related to the ${ }_{11} \mathrm{PO}_{4}{ }^{3-}$ one. Peaks at 1043 and $1073 \mathrm{~cm}^{-1}$ were associated to bending and stretching modes of carbonate $\left(\mathrm{CO}_{3}{ }^{2-}\right.$, type $\mathrm{B}$ carbonate), respectively ${ }^{36}$.

In the present work, the presence of peaks at 1043 and $1073 \mathrm{~cm}^{-1}$ indicating carbonate hydroxyapatite formation was also detected. Furthermore, peaks corresponding to the carbonate group of the calcium carbonate $\left(1088 \mathrm{~cm}^{-1}\right)^{37}$ were also detected for $25 \mathrm{wt} \% \mathrm{ZnO}$ (Figure $7 \mathrm{a}$ ) and $\mathrm{ZnO}-\mathrm{Bi}_{2} \mathrm{O}_{3}$ compositions, after treatment with sodium silicate (Figure $7 \mathrm{~b}$ ).

The sample $\mathrm{CACH}-\mathrm{ZnO}-\mathrm{Bi}_{2} \mathrm{O}_{3}$ was analyzed by grazing incidence $\mathrm{X}$-ray diffraction in order to determine the presence of crystalline phases of calcium phosphate on the samples surface. In order to increase the surface-to-bulk ratio signal, X-ray diffraction curves with incidence angles $\omega=0.25$, $0.5,1,5$ and $20^{\circ}$ were acquired for each sample. The curves were measured with a step of $0.01^{\circ}$ and integration time of $1 \mathrm{~s}$ per step. The results obtained are displayed in Figure 8, demonstrating the presence of crystalline calcium phosphate on the surface. The inset of Figure 8(a) shows the calculated intensity ratio between the $\mathrm{Ca}_{3}\left(\mathrm{PO}_{4}\right)_{2}(104)$ diffraction peak and its neighbor $\mathrm{NaCl}$ peak, indicated in the Figure by a dashed-arrow, as a function of the incidence angle. The ratio decreases exponentially as $\omega$ raises, reinforcing that calcium phosphate is only present on the surface of the samples, as expected. Since the calculated attenuation length of calcium phosphate is around $75 \mu \mathrm{m}$ for a perpendicular incidence, as shown in the inset of Figure 8(b), and the mean thickness of the surface layer is around tenths of nanometers, it was not possible to remove completely the bulk contribution from the analyses. However, the presence of the calcium phosphate related to X-ray diffraction peaks indicates the presence of a crystalline phase. The Scherrer equation was employed to calculate the mean size of the calcium phosphate ordered domains, resulting in values around $40 \mathrm{~nm}$. Some others samples were also evaluated but presented much difficulty to indentify the phosphate phase on surface due to signal/ noise ratio very high.

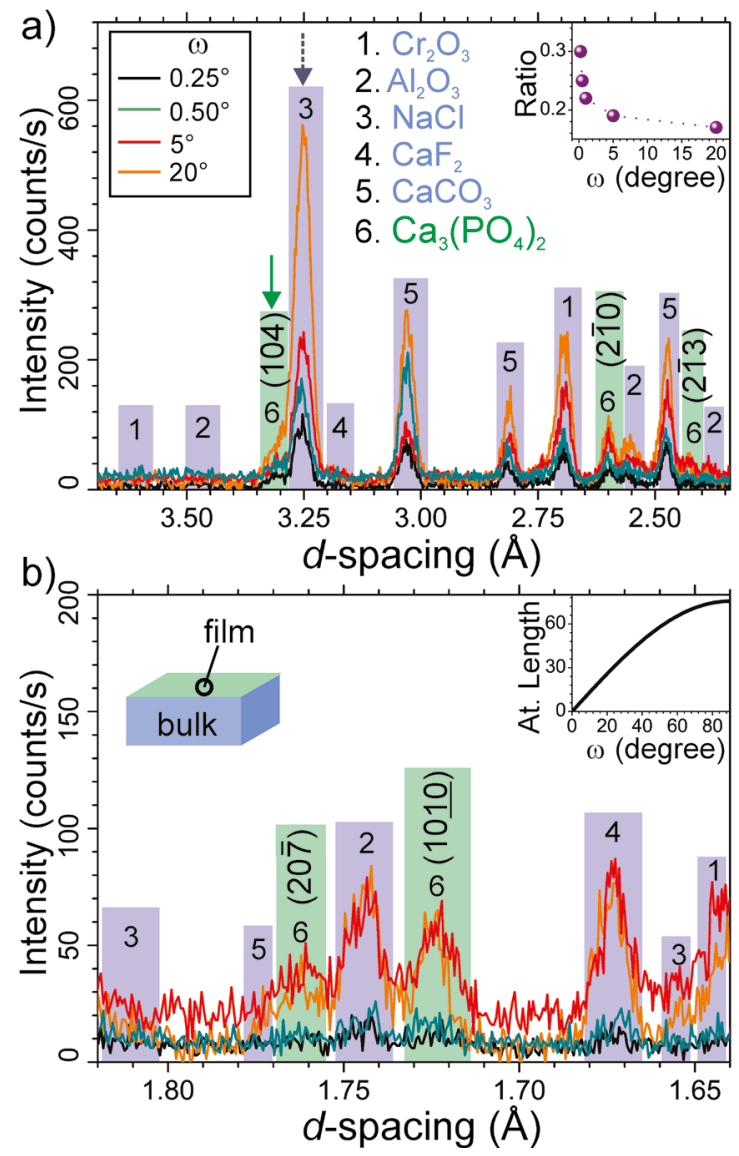

Figure 8. X-ray diffraction curves acquired at four different incident angles $\omega=0.25,0.5,5$ and $20^{\circ}$ as a function of the $d$-spacing for two different $2 \theta$ ranges. The diffraction peaks, relative to the substrate, are labeled by numbers from 1 to 5 , while the calcium phosphate peaks are indicated by number 6 , together with the respective Miller index $(h k l)$. (a) X-ray diffraction curves at low $2 \theta$ range. The inset shows the ratio intensity between bulk and surface peaks as a function of the incidence angle. (b) X-ray diffraction curves at high $2 \theta$ values. The inset displays the calculated attenuation length of calcium phosphate, in $\mu \mathrm{m}$, as a function of the incidence angle. 
Results of the cell viability test (MTT) and also macroscopic images of the cultures obtained for qualitative assessment of ALP activity in the presence of compositions are shown in Figure 9. MTT has a yellow color and it is reduced to insoluble purple formazan product when in contact with living cells. The complete solubilization of this precipitate results in a colored solution whose absorbance can be quantified.

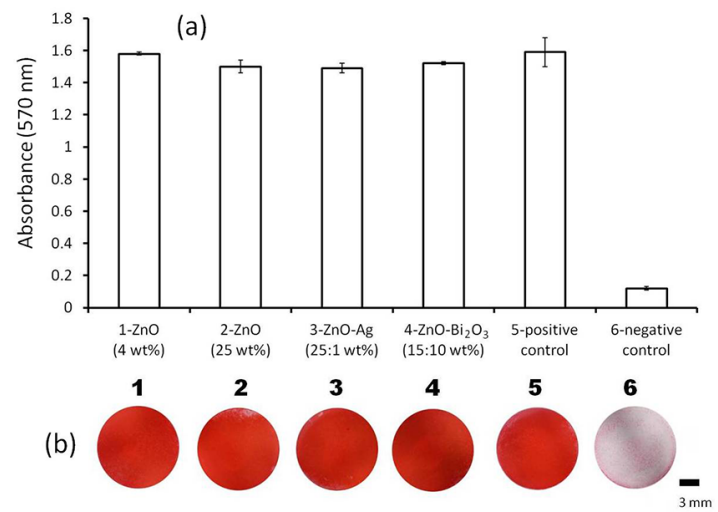

Figure 9. Cell viability (expressed as absorbance) after day 1 and macroscopic images of Fast red TR staining after day 7 of osteoblastic cells growth in the presence of CACH-ZnO (4 wt $\%)$, $\mathrm{CACH}-\mathrm{ZnO}(25 \mathrm{wt} \%)$, CACH-ZnO-Ag $(25: 1 \mathrm{wt} \%)$ and $\mathrm{CACH}-$ $\mathrm{ZnO}-\mathrm{Bi}_{2} \mathrm{O}_{3}(15: 10 \mathrm{wt} \%)$ compositions. Non-exposed cultures and those exposed to medium containing dimethyl sulfoxide (DMSO) at $10 \%$ were used as positive and negative controls, respectively.

The results highligthed higher cell viability for $4 \mathrm{wt} \%$ $\mathrm{ZnO}(1.58 \pm 0.01)$ samples and no significant difference when compared to the positive control (PC, $\mathrm{p}>0.05$ ). On the other hand, for samples of $25 \mathrm{wt} \% \mathrm{ZnO}, \mathrm{ZnO}-\mathrm{Ag}$ and $\mathrm{ZnO}-\mathrm{Bi}_{2} \mathrm{O}_{3}$ compositions, a significant reduction in the cell viability compared to the $P C$ one $(\mathrm{p}=0.005,0.003$ and 0.037 , respectively) was observed. $4 \mathrm{wt} \% \mathrm{ZnO}$ composition did not present any meaningful change with $\mathrm{ZnO}-\mathrm{Bi}_{2} \mathrm{O}_{3}(\mathrm{p}>0.05)$, whereas $\mathrm{ZnO}-\mathrm{Ag}$ and $25 \mathrm{wt} \% \mathrm{ZnO}$ difference was statistically significant ( $\mathrm{p}=0.013$ and 0.021 , respectively).

According to the literature, silver nanoparticles $(50 \mathrm{~nm})$ exhibit strong cytotoxic effects on osteoblasts and osteoclasts, whereas a weak cytotoxic effect is observed for their microparticles $(3 \mu \mathrm{m})^{38}$. Bismuth oxide-containing cement allows reduced cell viability, suggesting some cytotoxic effects. However, the thick biocoating, formed after 28-days in SBF, decreased the deleterious effect of bismuth oxide on cell growth ${ }^{39}$. Hidroxyapatite- $\mathrm{ZnO}$ composites containing $10 \mathrm{wt} \%$ or lower $\mathrm{ZnO}$, exhibited the ability to support cell adhesion and their proliferation ${ }^{40}$.

Increased cell viability, proliferation and ALP activity were also observed for CAC exposed osteogenic cell culture, which was partially attributed to the $\mathrm{Ca}^{2+}$ levels released by this cement ${ }^{41}$.

Regarding in vitro biological responses, the measurements of the alkaline phosphatase (ALP) activity are also important to assess the cell differentiation and the potential of the biological action of materials. ALP is a hydrolase enzyme present in the cells. In the alkaline phosphatase staining method, the enzyme hydrolyzes naphthol phosphate esters resulting in phenolic compounds and phosphates. The phenols attach to colorless diazonium salts (fast red TR) to produce insoluble, colored azo dyes (bright red) ${ }^{21}$.

The ALP activity of a specific composition could highlight its superior capacity to induce mineralization. Nevertheless, the compositions presented an intense color, but no clear differences were detected among them. Thus, it was clear that all cement compositions studied allowed osteoblastic differentiation in vitro.

\section{Conclusions}

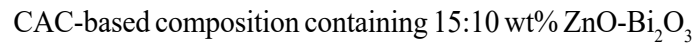
showed a suitable radiopacity value $(>3 \mathrm{mmAl})$. However, the one with $25: 1 \mathrm{wt} \% \mathrm{ZnO}-\mathrm{Ag}$, besides presenting suitable radiopacity (nearly $3 \mathrm{mmAl}$ ) for clinical purposes, provided a greater benefit as it does not induce mechanical strength decrease and $\mathrm{Ag}$ is added at a very lower content $(1 \mathrm{wt} \%)$.

Compositions $25 \mathrm{wt} \% \mathrm{ZnO}, 25: 1 \mathrm{wt} \% \mathrm{ZnO}-\mathrm{Ag}$ and $15: 10 \mathrm{wt} \% \mathrm{ZnO}-\mathrm{Bi}_{2} \mathrm{O}_{3}$ presented pore size decrease after interaction with SBF, indicating apatite precipitation on the materials' surface (bioactivity), which coated the solid surface and filled in the pores. The bioactivity was also indicated by the $\mathrm{pH}$ increase and the calcium ions decrease in the SBF and SBF/SS for all compositions studied.

SEM results confirmed that precipitation of the phases occurred on the surface of all compositions. The identification of calcium and mainly phosphorus by EDX and the Raman signature at $960 \mathrm{~cm}^{-1}$, corresponding to the phosphate group, attested the compositions' bioactivity after treatment with $\mathrm{SBF}$ or $\mathrm{SBF} / \mathrm{SS}$.

Regarding the osteoblastic cell viability, the CAC-blend containing $25 \mathrm{wt} \% \mathrm{ZnO}, 25: 1 \mathrm{wt} \% \mathrm{ZnO}-\mathrm{Ag}$ and $15: 10 \mathrm{wt} \%$ $\mathrm{ZnO}-\mathrm{Bi}_{2} \mathrm{O}_{3}$ presented slightly lower values compared to the positive control. On the other hand, no significant differences were detected for the ALP activity.

This work highlighted that among the studied blends, the $25: 1 \mathrm{wt} \% \mathrm{ZnO}-\mathrm{Ag}$ one, is the best to attain suitable radiopacity and presents a better balance when considering the bioactivity, cell viability and mechanical property values.

\section{Acknowledgements}

The authors would like to acknowledge the Brazilian Research Foundations: FAPESP (2016/15032-3; 2016/223665) and $\mathrm{CNPq}$ (301665/2015-0) for supporting this research, as well as Kerneos Aluminates (France) and Basf (Germany) for kindly supplying the CAC and dispersant samples, respectively. 


\section{References}

1. Lööf J. Calcium-Aluminate as Biomaterial: Synthesis, Design and Evaluation. [Thesis]. Uppsala: Uppsala University, Technology, Department of Engineering Sciences; 2008.

2. Kopanda JE, MacZura G. Production processes, properties and applications for calcium aluminate cements. In: Hart LD, ed. Alumina Chemicals: Science and Technology Handbook. Westerville: American Ceramic Society; 1990.

3. Engqvist H, Persson T, Löö J, Faris A, Hermansson L. Chemical Stability of a Novel Injectable Bioceramic for Stabilisation of Vertebral Compression Fractures. Trends in Biomaterials and Artificial Organs. 2008;21(2):98-106.

4. Parreira RM, Andrade TL, Luz AP, Pandolfelli VC, Oliveira IR. Calcium aluminate cement-based compositions for biomaterial applications. Ceramics International. 2016;42(10):11732-11738.

5. Seabra DEA. Studies of bioactivity of zinc oxide nanostructures. [Dissertation]. Aveiro: Aveiro University; 2013.

6. Mestre KML, Netto NG, Botta SB, Matos AB, Sobral MAP. The absence of radiopacity of some glass ionomer cements. Rev Odonto - Revista da Associação Paulista de Cirurgiões Dentistas. 2012;66(1):24-29.

7. Mestieri LB, Tanomaru-Filho M, Gomes-Cornélio AL, Salles LP, Bernardi MIB, Guerreiro-Tanomaru JM. Radiopacity and cytotoxicity of Portland cement associated with niobium oxide micro and nanoparticles. Journal of Applied Oral Science. 2014;22(6):554-559.

8. Cruvinel DR, Garcia LFR, Casemiro LA, Pardini LC, Piresde-Souza FCP. Evaluation of radiopacity and microhardness of composites submitted to artificial aging. Materials Research. 2007;10(3):325-329.

9. Tirapelli C, Panzeri FC, Panzeri H, Pardini LC, Zaniquelli O. Radiopacity and microhardness changes and effect of X-ray operating voltage in resin-based materials before and after the expiration date. Materials Research. 2004;7(3):409-412.

10. Aguilar FG, Garcia LFR, Rossetto HL, Pardini LC, Panzeri Pires-de-Souza FC. Radiopacity evaluation of calcium aluminate cement containing different radiopacifying agents. Journal of Endodontics. 2011;37(1):67-71.

11. Van Noort R, Barbour ME. Introduction to Dental Materials. $4^{\text {th }}$ ed. Saint Louis: Mosby Elsevier; 2013.

12. Camilleri J, Gandolfi MG. Evaluation of the radiopacity of calcium silicate cements containing different radiopacifiers. International Endodontic Journal. 2010;43(1):21-30.

13. Oliveira IR, Andrade TL, Matsuo DC, Parreira RM, Jacobovitz $\mathrm{M}$, Pandolfelli VC. Influence of radiopacifier additives on calcium aluminate cement properties. Materials Research. 2014;17(5):1295-1301.

14. Ohtsuki C, Kamitakahara M, Miyazaki T. Bioactive ceramicbased materials with designed reactivity for bone tissue regeneration. Journal of the Royal Society, Interface. 2009;6(Suppl 3):S349-S360.

15. Kokubo T, Takadama H. How useful is SBF in predicting in vivo bone bioactivity? Biomaterials. 2006;27(15):2907-2915.
16. Wu C, Xiao Y. Evaluation of the In Vitro Bioactivity of Bioceramics. Bone and Tissue Regeneration Insights. 2009;2. DOI: $0.4137 /$ BTRI.S3188

17. Oliveira IR, Pandolfelli VC, Jacobovitz M. Chemical, physical and mechanical properties of a novel calcium aluminate endodontic cement. International Endodontic Journal. 2010;43(12):10691076.

18. Rigo ECS, Boschi AO, Yoshimoto M, Allegrini S Jr., Konig B Jr., Carbonari MJ. Evaluation in vitro and in vivo of biomimetic hydroxypaptite coated on titanium dental implants. Materials Science and Engineering: C. 2004;24(5):647-651.

19. Wang X, Sun $\mathrm{H}$, Chang J. Characterization of $\mathrm{Ca}_{3} \mathrm{SiO}_{5} / \mathrm{CaCl}_{2}$ composite cement for dental application. Dental Materials. 2008;24(1):74-82.

20. Mosmann T. Rapid colorimetric assay for cellular growth and survival: application to proliferation and cytotoxicity assays. Journal of Immunological Methods. 1983;65(1-2):55-63.

21. Silva RA, Leonardo MR, Silva LA, Castro LM, Rosa AL, Oliveira PT. Effects of the association between a calcium hydroxide paste and $0.4 \%$ chlorhexidine on the development of the osteogenic phenotype in vitro. Journal of Endodontics. 2008;34(12):1485-1489.

22. Demirtas TT, Kaynak G, Gümüsderelioglu M. Bone-like hydroxyapatite precipitated from $10 \times$ SBF-like solution by microwave irradiation. Materials Science and Engineering: C. 2015;49:713-719.

23. Silva CCG, Rigo ECS, Marchi J, Bressiani AHA, Bressiani JC. Hydroxyapatite coating on silicon nitride surfaces using the biomimetic method. Materials Research. 2008;11(1):47-50.

24. Reis RL, Román JS. Biodegradable Systems in Tissue Engineering and Regenerative Medicine. Boca Raton: CRC Press; 2004.

25. Oliveira IR, Andrade TL, Jacobovitz M, Pandolfelli VC. Bioactivity of calcium aluminate endodontic cement. Journal of Endodontics. 2013;39(6):774-778.

26. Liu W, Chang J. Setting properties and biocompatibility of dicalcium silicate with varying additions of tricalcium aluminate. Journal of Biomaterials Applications. 2011;27(2):171-178.

27. Godley R, Starosvetsky D, Gotman I. Corrosion behavior of a low modulus beta-Ti- $45 \% \mathrm{Nb}$ alloy for use in medical implants. Journal of Material Science. Materials in Medicine. 2006;17(1):63-67.

28. Ehara A, Ogata K, Imazato S, Ebisu S, Nakano T, Umakoshi Y. Effects of alpha-TCP and TetCP on MC3T3-E1 proliferation, differentiation and mineralization. Biomaterials. 2003;24(5):831-836.

29. Gustavsson J, Ginebra MP, Engel E, Planell J. Ion reactivity of calcium-deficient hydroxyapatite in standard cell culture media. Acta Biomaterialia. 2011;7(12):4242-4252.

30. Silva Junior PE, Oréfice RL. Compósitos Bioativos Obtidos a Partir da Inserção de Vidro Bioativo em Matriz de Poli(Metacrilato de Metila). Polímeros. 2001;11(3):109-115.

31. Khorami M, Hesaraki S, Behnamghader A, Nazarian H, Shahrabi S. In vitro bioactivity and biocompatibility of lithium substituted 45S5 bioglass. Materials Science and Engineering: C. 2011;31(7):1584-1592. 
32. Engqvist H, Schultz-Walz JE, Loof J, Botton GA, Mayer D, Phaneuf MW, et al. Chemical and biological integration of a mouldable bioactive ceramic material capable of forming apatite in vivo in teeth. Biomaterials. 2004;25(14):2781-2787.

33. Pucéat E, Reynard B, Lécuyer C. Can crystallinity be used to determine the degree of chemical alteration of biogenic apatites? Chemical Geology. 2004;205(1-2):83-89.

34. Markovic S, Veselinovic L, Lukic MJ, Karanovic L, Bracko I, Ignjatovic N, et al. Synthetical bone-like and biological hydroxyapatites: a comparative study of crystal structure and morphology. Biomedical Materials. 2011;6(4):045005.

35. Silva MJ, ed. Skeletal Aging and Osteoporosis: Biomechanics and Mechanobiology. New York: Springer; 2013.

36. Berger SB, Soares LES, Martin AA, Ambrosano GMB, Tabchoury CPM, Giannini M. Effects of various hydrogen peroxide bleaching concentrations and number of applications on enamel. Brazilian Journal of Oral Sciences. 2014;13(1):22-27.

37. Sun J, Wu Z, Cheng H, Zhang Z, Frost RL. A Raman spectroscopic comparison of calcite and dolomite. Spectrochimica Acta Part A: Molecular and Biomolecular Spectroscopy. 2014;117:158-162.
38. Albers CE, Hofstetter W, Siebenrock KA, Landmann R, Klenke FM. In vitro cytotoxicity of silver nanoparticles on osteoblasts and osteoclasts at antibacterial concentrations. Nanotoxicology. 2013;7(1):30-36

39. Gandolfi MG, Ciapetti G, Perut F, Taddei P, Modena E, Rossi PL, et al. Biomimetic calcium-silicate cements aged in simulated body solutions. Osteoblast response and analyses of apatite coating. Journal of Applied Biomaterials \& Biomechanics. 2009;7(3):160-170.

40. Saha N, Dubey AK, Basu B. Cellular proliferation, cellular viability, and biocompatibility of HA-ZnO composites. Journal of Biomedical Materials Research. Part B: Applied Biomaterial. 2012;100(1):256-264.

41. Castro-Raucci LMS, Teixeira LN, Oliveira IR, Raucci-Neto W, Jacobovitz M, Rosa AL, et al. Osteogenic cell response to calcium aluminate-based cement. International Endodontic Journal. 2017;50(8):771-779. DOI: 10.1111/iej.12682 